\title{
O TŁUMACZENIACH LIRYKÓW TYMOTEUSZA KARPOWICZA PRZEZ KARLA DEDECIUSA
}

\begin{abstract}
Zarys treści. W artykule podjęto próbę przeprowadzenia analizy i oceny tłumaczeń dwóch wierszy Tymoteusza Karpowicza, Czarne i białe oraz Trudny las, dokonanych przez Karola Dedeciusa. Oceniając dokonania tłumacza, autorka wychodzi od jego własnych przemyśleń dotyczących tłumaczenia liryki, co można uznać za próbę odpowiedzi na pytanie, na ile Dedecius, tłumacząc oba utwory, konsekwentnie realizował swoją teorię. W konkluzji wyrażono pogląd, iż tłumacz kierował się priorytetem brzmienia, będąc przy tym sprawiedliwym¹ wobec poszczególnych słów, zwrotów i zdań, tracąc jednakże całościowy sens utworu. Poza tym zwrócono uwage, iż Dedecius czyta Karpowicza przez pryzmat twórczości Leśmiana i poetów awangardowych. Zarzucono tłumaczowi, że nie dostrzega występującej w lirykach Karpowicza problematyki metajęzykowej.
\end{abstract}

Wohin ein braves, gedankenloses Übersetzen führen kann, das zeigen die zahlreichen Kuriosa dieser Praxis

(Dedecius 1981: 27).

$D^{2}$ edecius jest jedynym w Niemczech tłumaczem, który zajmuje się polską poezją lingwistyczną. Stara się w swych przekładach naśladować zarów-

${ }^{1}$ Dedecius proponuje zastąpić nadużywane przez tłumaczy, niejasne pojęcie wierności wobec sensu (ein vager Begriff), określeniem: sprawiedliwość wobec sensu (Sinn - Gerechtigkeit), które - zdaniem tłumacza - jest bardziej wymierne, obiektywne. Sprawiedliwość obejmuje niemal wszystkie zakresy ludzkiej działalności, np: społeczną i polityczną czy prawną lub gospodarczą, co zobowiązuje tłumacza do dużej odpowiedzialności w czasie przekładu (Dedecius 1996: 84). 
no materię fonetyczną ${ }^{2}$, frazeologię ze składnią, jak i leksykę, a także przekształcenia znaczeniowe, które np. w wierszach autora Trudnego lasu wynikają z dekompozycji związków frazeologicznych, co jest niewątpliwie wyznacznikiem poetyki Karpowicza po 1960 roku. Wyznaje, że nie mógłby być tłumaczem, gdyby nie poszukiwał właściwych słów do wyrażenia sensów, które zamierza nadać przekładanym przez niego dziełom pióra polskich autorów, wbijając w nie jednocześnie klin swej woli (Dedecius 1988: 67). Podkreśla, że interpretacja jednostek leksykalnych w pierwotnym otoczeniu literackim, w które zostały uwikłane, pozwala odnaleźć ich sens. Same słowa są surowym materiałem. Nabierają życia dopiero wtedy, kiedy tłumacz nada im znaczenie. Przedtem jednak musi podjąć próbę ich interpretacji, sprawdzić, w jakie wchodzą związki z kontekstem przekładanego utworu. Celem artykułu jest sprawdzenie, jak postępuje tłumacz, aby - parafrazuję Dedeciusa - „ożywić” słowa (1988: 67) w dokonanych przez siebie przekładach liryków polskich poetów lingwistycznych na materiale tłumaczeń dwóch wierszy Tymoteusza Karpowicza: Czarne i białe (Schwarz und wei $\beta$ ) oraz Trudny las (Schwieriger wald). Podejmuję również próbę spojrzenia na analizowane tutaj przekłady z perspektywy ich odbiorców ${ }^{3}$. Takie spojrzenie utrudnione jest niedostatkiem prac naukowych oraz recenzji poświęconych twórczości lirycznej Karpowicza, autorstwa Dedeciusa czy też innych niemieckich tłumaczy, a także slawistów niezajmujących się działalnością translatorską.

Przekład traktowany jest tutaj jako świadectwo odbioru, tzn. że w centrum moich zainteresowań znajdują się indywidualne decyzje tłumacza,

\footnotetext{
${ }^{2}$ Nieprzypadkowo we wszystkich wersjach przekładu liryku Zbigniewa Herberta pt. Kamyk (Herbert 1964: 59) Dedecius zastępuje słowo kamyk (dosł. Steinchen, ein kleiner Stein) jednostką leksykalną Kiesel (dosł. krzemień, krzemieniak, krzem) (Dedecius 1968: 76; 1974: 3; 1979: 16; 1987: 34; 1996: 147; 2000: 178). Przez zastosowanie wskazanej immutacji naśladuje nie tylko - zwracają uwagę Schultze i Matuschek - dwusylabiczność występującego w oryginale wyrazu $\boldsymbol{k} a-m y k$ (Kie-sel), ale także głoskę $\boldsymbol{k}$ w nagłosie (B. Schultze, Matuschek 2005).

${ }^{3} \mathrm{~W}$ dokonywanych przeze mnie próbach spojrzenia na twórczość Karpowicza z perspektywy niemieckiego odbiorcy pomogli mi prof. Brigitte Schultze z Instytutu Slawistyki (Johannes Gutenberg Universität w Moguncji) oraz Hans-Georg Oertgen, germanista i teolog z Kaiserslautern, współautor zaprezentowanych przeze mnie w niniejszym szkicu przekładów „alternatywnych”. Rozmowa z prof. Schultze oraz udostępniony mi przez nią artykuł (wówczas jeszcze niepublikowany), pt. Sprachliche Asymmmetrien als Beobachtungsort polnisch-deutscher literarischer Übersetzungen (2005), który napisała wspólnie z Herbertem Matuschkiem, okazały się pomocne w przeprowadzonych tutaj analizach porównawczych.
} 
uwarunkowane jego kulturą literacką, niewynikające z języka, na który się przekłada (Głowiński 1977: 122; Dedecius 1981: 128), chociaż zwracam niekiedy uwagę na różnice między oryginałem a przekładem, warunkowane odmiennością dwóch systemów językowych. W sytuacji, w której występuje tzw. asymetria językowa (Schultze, Matuschek 2005) tłumacz musi zastąpić słowa, wyrażenia i zwroty, występujące w oryginale, jednostkami leksykalnymi, które nie są wprawdzie ich językowymi ekwiwalentami, ale oddają sens oryginału, musi zatem dokonać trafnego wyboru. W ten sposób daje wyraz swej interpretacji literackiego pierwowzoru. Ma pełną świadomość potrzeby uwzględniania w przekładzie adresata, który mówi innym językiem niż autor oryginału, a zarazem ukształtowany jest przez inną tradycję kulturową. Ostrzega potencjalnych tłumaczy przed próbami dokonywania przekładów dosłownych, którymi można autorom utworów oryginalnych - jak sam się wyraził - wyrządzić niedźwiedzią przysługę (Dedecius 1981: 128). Zdaniem Dedeciusa każdy tłumacz zmuszony jest do szukania kompromisu między przymusem a swobodą (Dedecius 1988: 27). Nie może jednak zrezygnować - podkreślał Schlegel - z estetycznego odbioru dzieła literackiego (Schlegel 1928: 36-42). Zamierzam sprawdzić, czy w przeprowadzonych tutaj analizach przekładów wybranych liryków Karpowicza udało się to Dedeciusowi. Interesuje mnie również, jakimi metodami przekładu posługuje się tłumacz, aby zostać - jak sam się wyraził - sprawiedliwym wobec sensu (Dedecius 1996: 84-85) literackiego pierwowzoru. Metodami, które określone zostały tutaj - tak jak to uczynił Ziomek - pojęciami znanymi ze starożytnej retoryki są np. immutacja, polegająca na zastąpieniu polskiego słowa, wyrażenia lub zwrotu niemieckim, które nie jest jego ekwiwalentem, ale oddaje całościowy sens oryginału, adiekcja, przejawiająca się we wprowadzaniu do przekładu dodatkowych słów, których nie znajdujemy w oryginale, lub detrakcja, czyli opuszczanie w przekładzie wyrazów, a nawet obszernych fragmentów utworu oryginalnego. Należałoby jeszcze wymienić transmutację, polegającą np. na celowej zmianie szyku wyrazów w zdaniu czy też „przestawieniu” przez tłumacza wybranych sekwencji utworu (Ziomek 1980: 355-387). Respektowane są tutaj przeze mnie uwagi Dedeciusa na temat twórczości Leśmiana oraz polskich poetów awangardowych. Lektura ich utworów miała bez wątpienia duży wpływ na „odczytanie” przez tłumacza twórczości poety, czego próbuję tutaj dowieść (Leśmian 1988, 1996: 117-136; Dedecius 1968: 199). Właśnie w Leśmianowskim symbolizmie i refleksyjności wierszy autora Trudnego lasu, a także w dekomponowaniu - wzorem poetów Zwrotnicy - utartych związków frazeologicznych, a zarazem w „przesuwaniu” asocjacji, przeja- 
wiają się - zdaniem Dedeciusa - formy niepokoju (Formen der Unruhe) w utworach polskiego poety (1968: 210), co znajduje artystyczny wyraz w przekładach dokonanych przez kochanka polskich muz (Naganowski 1972: 5). Dodam, że Dedecius interesuje się także twórczością autorów awangardowych, o czym świadczą np. takie jego prace, jak: Versuch der Ganzheit. JULIAN PRZYBOŚ und der poetische Sinn (Dedecius 1975: 147-195) oraz Julian Przyboś: Poesie und Poetik (Przyboś 1989) czy też jego wypowiedzi o Przybosiu i Peiperze pomieszczone w posłowiach do takich antologii, jak np.: Die Dichter Polens (Dedecius 1982: 132-133) czy wspomnianej już Polnische Poesie des 20. Jahrhunderts (1968: 215-219).

\section{Między dosłownością a sprawiedliwością wobec sensu (Sinn-Gerechtigkeit)}

Dedecius zdaje się pamiętać o tym, że Karpowicz - cytuję słowa tłumacza - alte Worte zu neuen logischen Formationen mobilisiert (1982: 134), co przejawia się w tworzeniu zaskakujących kombinacji słownych, które mogą być niezrozumiałe dla niemieckiego odbiorcy. Zależy mu na tym, aby przekład reprezentował literacki pierwowzór (Mróz 1977: 41), co znajduje m.in. wyraz, np. w tłumaczeniu liryku pt. Czarne i białe (Schwarz und weiß) ze zbiorku pt. Znaki równania (Gleichheitszeichen):

CZARNE I BIALE: W konarach światła/ i korzeniach nocy/ wyrasta nasz wzrok//\# Czarni i biali ludzie/ przestępuja nam/z dłoni na dłoń//\# Białe i czarne zwierzęta/ liżą nasze/światłoczułe włosy//\# Zakochani w wyraźnym/ całujemy podwójne oczy/ wiecznych kolorów//\# Nic nam bardziej strasznego/ zdarzyć się / nie możel/\# od szarej gałązki/ co zapuka/ w okno (podkr. K. K. - Karpowicz 1958: 52) [Schwarz und weiß: aus den kronen des lichts/ und den wurzeln der nacht/ wächst uns der blick//\# schwarze und weiße menschen/ wechseln von einer hand/ zur anderen//\# weiße und schwarze tiere/ lecken unsere/ lichtempfindlichen haare//\# nichts schimmeres/ kann uns/ passieren//\# als daß ein graues zweiglein/ anklopft/ ans fenster] (podkr. K. K. - Dedecius 1968: 121).

Dedecius w pierwszym wersie posługuje się metodą immutacji, zastępując polski wyraz: konary niemieckim: Kronen (korony). Gdyby przełożył go dosłownie (das Geäst lub Zweige), oddałby bez trudu sytuację przedstawioną w oryginale. Występujące w analizowanym przekładzie wyrażenie: aus den kronen des lichts warto byłoby zastąpić innym: Durch die Zweige des 
Lichts, co pozwoliłoby oddać zmagania poznawcze bohatera lirycznego, próbującego dostrzec światło przysłonięte przez rosnące za oknem drzewa, a zatem poznać to, co nie jest obiektem naszej bezpośredniej obserwacji. W związku z tym zasadne byłoby zastąpienie występującego w przekładzie słowa Blick wyrazem Sicht, które w większym stopniu, niż zastosowana przez Dedeciusa jednostka leksykalna, generuje grę znaczeń, która występuje w oryginale: konotuje zarówno widzenie, jak i stanowisko wobec czegoś (Einstellung) albo punkt widzenia (Blickwinkel, Standpunkt, Gesichtspunkt). Ostatnie z podanych znaczeń eksponuje sens literackiego pierwowzoru, w którym przedstawiona jest niechęć „ja” mówiącego do czarno-białych kwalifikacji, co mocno zostało zaakcentowane przez poetę w tomie pt. Odwrócone światło (Karpowicz 1972). Tłumacz posługuje się „,zbitką” słowną der Blick wächst uns, prawdopodobnie w celu zaszokowania odbiorcy literackiego zaskakującym połączeniem słów (Krasoń 2003: 118), co czynił często Karpowicz. Można przypuszczać, że chce w ten sposób zwrócić uwagę na związki poety z tradycją awangardową. Zastosowaną przez tłumacza "zbitkę" słowną można byłoby zastąpić zwrotem unsere Sicht entsteht, który przypuszczalnie nie budziłby sprzeciwu adresata przekładu, a zarazem wskazywałby na proces poznawczy bohatera lirycznego. Bohatera, który próbuje zrozumieć świat postrzegany z określonego punktu widzenia, w kolejnych „odsłonach”: w pierwszej z nich pojawiają się rośliny okryte gdzieniegdzie poświatą księżyca, widoczną między konarami drzew, w drugiej: ludzie, a w trzeciej zwierzęta, co nasuwa skojarzenie z podziałem istot żyjących, dokonanym przez Arystotelesa w Etyce nikomachejskiej: rozumna (ludzie), czująca (ludzie i zwierzęta) i wegetatywna (ludzie, zwierzęta, rośliny) część duszy vernünftiger, empfindender i vegetativer Seelenteil (Aristoteles 1992: 10-16). Wynika z tego, że obraz poetycki w oryginale - tak jak obrazy tworzone przez poetów awangardowych - jest kreowany według z góry ustalonego planu, co stara się tłumacz respektować w swym przekładzie. Dedecius przecież podziwia w lirykach autora Sensu poetyckiego, będącego wielkim poprzednikiem Karpowicza - symetrię i porządek ${ }^{4}$. Utwory autora Oburącz porównuje do masywnych i trwałych budowli o mocnych fundamentach (Dedecius 1975: 150-151). Można przypuszczać, że charakteryzowane przez tłumacza zasady kompozycji utworów lirycznych Przybosia zauważa u Karpowicza, co stara się oddać w przekładzie.

${ }^{4}$ O postrzeganiu poetyckim Karpowicza i Przybosia oraz o zasadach kompozycji ich utworów pisałam w następujących pracach: Krasoń 2000: 417-423; 2002: 79-92; 2004: 33-40. 
Dedecius decyduje się na dosłowne tłumaczenie pierwszego wersu drugiej strofy: Czarni i biali ludzie (podkr. - K. K.) [Schwarze und weiße menschen ${ }^{\star}$ (podkr. K. K.)], co utrudnia mu oddanie sensu, wynikającego z literackiego pierwowzoru, który może być nieuchwytny dla niemieckiego czytelnika, ponieważ adresat przekładu nie musi wiedzieć, iż oba kolory oznaczają u Polaków określone typy ludzkie. Niemcy - w przeciwieństwie do Polaków - nie posługują się wyrażeniem: czarny charakter [ein schwarzer Charakter*], określającym osobę, której przypisuje się wyłącznie cechy negatywne. Przełożone dosłownie przez Dedeciusa epitety (czarny i biały) mogą kojarzyć się niemieckiemu czytelnikowi np. z ludzką rasą. W związku z tym zasadne byłoby inne tłumaczenie przywołanego wersu: dunkle und helle Menschentypen, co pozwoliłoby nie tylko zachować znaczenie wynikające $z$ literackiego pierwowzoru, ale także przybliżyć je adresatowi przekładu, przekonać go, że biel i czerń odnosi się w liryku Karpowicza zarówno do wspomnianego już, „jednoznacznego” widzenia rzeczywistości - wynikającego z lęku przed tym, co „wymyka się” naszemu potocznemu doświadczeniu (Szmydt 1958: 12; Krasoń 2001: 125-127), jak i dotyczy typów ludzkich charakterów. Myśl ta zostałaby mocniej podkreślona, gdyby w przekładzie zastąpiono polskie słowo wyraźny, które zostało przez Dedeciusa przełożone dosłownie deutlich - niemiecką jednostką leksykalną eindeutig (jednoznaczny). Przed zastosowaniem immutacji powstrzymała tłumacza najprawdopodobniej jego dążność do tego, aby przekład nie tyle naśladowat, co odwzorowywał zarówno prozodię, jak i leksykę literackiego pierwowzoru.

W przekładzie przywołanego liryku próbuje również reprezentować Dedecius podchwycone przez siebie związki Karpowicza z tradycją awangardową, np. naśladowanie - powiedzmy za de Saussurem - obrazu akustycznego (Saussure 1961: 43) literackiego pierwowzoru czy też pseudonimowanie, a także całościowe w (sensie Heglowskim) - znane z poezji Przybosia - postrzeganie świata, na temat którego pisał dość często: W przyczynku do dzieła pt. $<<$ Sens poetycki<<, zamieszczonego pod tym samym nagłówkiem, cytowane sa słowa Hegla: »To, co prawdziwe jest całościq̨" (Dedecius 1975: 157 - tłum. K. K). Przyboś jest - uważa tłumacz - poetologiczną bazą wyjściową do tego, aby opisywać jak najprościej i jak najogólniej. Artystycznym wyrazem podjętych przez poetę prób tworzenia całości są niezwykle plastyczne obrazy poetyckie (1975: 157). Analiza utworu pt. Czarne i białe oraz jego przekładu, w którym została oddana „symetryczna” kompozycja wiersza - dowiodła, że Dedecius w swym tłumaczeniu akcentuje, iż dla autora Trudnego lasu - tak samo, jak dla Przybosia - poeta powinien odznaczać się 
wiarą w scalającą moc umysłu, którą Hegel uważał za warunek wszystkich filozofii. Tłumacz chce to szczególnie zaakcentować przez próbę odwzorowania w przekładzie leksyki oraz kompozycji oryginału. Innymi słowy decyduje się na przekład dosłowny, co prowadzi niekiedy do zerwania porozumienia między nadawcą utworu oryginalnego a adresatem przekładu ${ }^{5}$.

Jednym z najtrudniejszych zadań jest podjęta przez Dedeciusa próba przekładu liryku Karpowicza pt. Trudny las - utworu wielowarstwowego, mieniącego się bogactwem znaczeń, w którym został wyrażony - często poruszany przez Karpowicza - problem nieprzystawalności rzeczy do nazwy. Tłumacz zdobył się jednak na odwagę wejścia do, zdającego się nie mieć końca, labiryntu słów i znaczeń. Sprawdźmy, czy wędrując po ciemnych i krętych korytarzach, nie zabłądził:

TRUDNY LAS: co wykopię jego zieleń z brunatnego dołu/ obsuwa się pod moja białość//\# co podniose go $z$ kolan na gatęzie/ opada z moich nóg//\# ledwo dam mu słowo między drzewami/ już je upuszcza na mój głos/zanim pokaże mu wesołe wiewiórki/ zdą̇y się oślepić na mój widok//\# cóż to za trudny las unicestwiam/ pragnieniem jego szumu (podkr. K. K. - Karpowicz 1962: 23) [Schwieriger wald: sobald ich sein grün aus dem braunen loch heraus grabe/ rutscht er unter mein weiß//\# sobald ich ihn von den knien auf die zweige hebe/ fällt er von meinen beinen//\# *[...]!!!//\# bevor ich ihm die lustigen eichkatzen zeige/ erblindet er bei meinem anblick//\# was ist das nur für ein schwieriger wald den ich vernichte/ mit dem wunsch nach seinem rauschen] (podkr. - K. K., Dedecius 1968: 131).

Wątpliwości budzi zaproponowane przez Dedeciusa dosłowne tłumaczenie tytułu wiersza (der schwierige wald), które jest bardzo enigmatyczne. Potoczne doświadczenie językowe nakazuje przecież adresatowi przekładu zapytać, co symbolizuje las, o którym mówi się w utworze Karpowicza i dlaczego jest „trudny”?... Na pewno odpowiedzi na pytanie zdezorientowanego czytelnika nie umożliwi lektura przekładu, bowiem Dedecius opuszcza fragment utworu oryginalnego, będącego kluczem interpretacyjnym do tłumaczonego liryku: ledwo dam mu słowo między drzewami/

${ }^{5}$ Oto propozycja przekładu równie polemicznego, analizowanego tutaj liryku Karpowicza: Schwarz und Weiß: Durch Zweige des Lichts/ Und Wurzeln der Nacht/ entsteht unsere Sicht///\# dunkle und helle Menschentypen/ springen von einer Hand/zur anderen //\# weiße und schwarze Tiere/ lecken unsere/ lichtempfindlichen Härchen//\# In das Eindeutige verliebt/ küssen wir die beiden Augen/ der ewigen Farben//\# Nichts Schlimmeres/ kann uns/ passieren//\# als dass ein graues Zweiglein/ an unser Fenster/ klopft (tłum. K. K.). 
już je upuszcza na mój głos (podkr. K. K). Fragment, w którym została wyrażona refleksja podmiotu lirycznego - tożsamego $\mathrm{z}$ autorem - nad językiem jako środkiem komunikacji. Można przypuszczać, że pod wskazanym słowem-kluczem, mieniącym się w lirykach poety różnymi znaczeniami symbolicznymi, kryje się - jak słusznie zauważa Barańczak - wszystko, co skomplikowane, co nie poddaje się określeniu [...], co należy zrozumieć, czego nie wolno powierzchownie objaśniać naszym schematycznym językiem i potoczna logika (Barańczak 1971: 67). Karpowicz w przywołanej, a opuszczonej przez Dedeciusa sekwencji utworu, „wyzyskuje” dwuznaczność związku frazeologicznego: daję słowo (ozn. nazywam, a także przyrzekam). Z wiersza wynika, że „ja” liryczne próbuje nawiązać porozumienie z lasem poprzez próbę nazwania go, ponieważ dla Karpowicza - przypominam słowa Lipskiego - warunkiem istnienia rzeczy jest jej znaczenie. A każda rzecz istnieje w nazwie (Lipski 1962: 94). Przedmiot poznania wymyka się jednak wszelkim wyjaśnieniom: las [...] upuszcza je (słowa - wtrąc. K. K) na mój głos. Tłumacz zdaje się nie zauważać w analizowanym liryku wspomnianej refleksji poety nad językiem. Przeoczony przez Dedeciusa dystych dałoby się przełożyć w sposób następujący: bevor ich noch seine bäume benennen kann/ versagt mir die stimme [Zanim jeszcze mogę nazwać jego drzewa/ odmawia mi posłuszeństwa (zawodzi mnie) głos]. Dedeciusowi obca jest jednak podjęta w liryku Karpowicza problematyka metajęzykowa, z przekładu wynika bowiem, że w wierszu jest mowa o pasowaniu się człowieka z przyrodą. Leśmianowski panteizm występuje wprawdzie w lirykach poety, ale nie stanowi wyłącznej differentiae specificae przywołanego wiersza. Nic dziwnego, że Dedecius przekłada ostatnią strofę w sposób następujący: was ist das nur ein schwieriger wald den ich vernichte/ mit dem wunsch nach seinem rauschen (podkr. K. K.). Posługuje się instrumentacja głoskowa - niewystępującą w oryginale(!) - mającą ilustrować szum lasu, który pragnie usłyszeć bohater liryczny. Zatem stosuje metodę immutacji, polegającą na zastąpieniu jednostki leksykalnej: pragnąć, pożądać (begehren) niemieckim wyrażeniem: mit dem Wünsch, które nie oddaje - w takim stopniu, jak słowo begehren, pragnienia bohatera lirycznego, dążącego do poznania i ujęcia w nazwie przedmiotu obserwacji, ale za to umożliwia tłumaczowi wywołanie wspomnianego efektu dźwiękowego, będącego brzmieniową ilustracją szelestu liści. Nic nie stoi na przeszkodzie przełożenia zamykającego utwór dystychu w taki sposób, aby zbliżyć się bardziej do oryginału, czyli zachować wspomnianą sprawiedliwość wobec sensu, wynikającego z liryku Karpowicza (Dedecius 1996: 85): welch finstren wald zerstöre ich/ wenn ich sein rauschen zu hören begehre. W zaproponowanym tutaj tłuma- 
czeniu ostatniej strofki pojawił się, oprócz instrumentacji głoskowej, także rym paroksytoniczny: zerstöre \|| begehre, który nie występuje wprawdzie w liryku Karpowicza, ale pełni w analizowanym tłumaczeniu istotną funkcję. Jest "klamrą” spinającą ostatni dystych, będący zarówno w oryginale, jak i w przekładzie jakby podsumowaniem poznawczych zmagań „ja” lirycznego ${ }^{6}$.

Z powyższej analizy porównawczej dwóch wersji przekładu tego samego - jakże wieloznacznego(!) - liryku pt. Trudny las wynika, że tłumaczowi nie udało się wejść w głąb zbudowanego przez Karpowicza labiryntu słów i znaczeń.

\section{Podsumowanie}

Przedstawiona tutaj analiza przekładów Dedeciusa, przeplatana krytycznymi uwagami - nie świadczy o tym, że podaję w wątpliwość zasługi wybitnego tłumacza, udającego się w podróż po labiryntach znaczeń.

Z analizy przekładów liryków Karpowicza wynika, że tłumacz stara się być - stosuję określenie Dedeciusa - „sprawiedliwy” (Dedecius 1996: 84) wobec poszczególnych słów, zwrotów i zdań, przez co gubi całościowy sens utworu. Próbuje imitować kształt materiału językowego literackiego pierwowzoru, co przejawia się w przestrzeganiu członkowania rytmicznego i zasad kompozycji tekstu oryginalnego, mających awangardową proweniencję. Niewątpliwie priorytet przyznaje brzmieniu, a nie znaczeniu. $\mathrm{Ma}$ pełną świadomość niebezpieczeństw, jakie niesie ze sobą pokusa przekładu

${ }^{6}$ Oto propozycja przekładu wiersza pt. Trudny las (Der finstere Wald), która może być podstawą kolejnej dyskusji: wenn ich das grün aus der braunen grube grabe/ verschwindet es hinter meiner helligkeit/ wenn ich ihn kniend wegen der zweige anhebe/ verliere ich ihn unter meinen füßen/ bevor ich noch seine bäume benennen kann/versagt mir die stimme/ bevor ich ihm die lustigen Eichhörnchen zeige/ erblindet er durch meinen Anblick/ welch finstren wald zerstöre ich/ wenn ich sein rauschen zu hören begehre (tłum. K. K.). Podkreślone zostały fragmenty, w których wystąpiła instrumentacja głoskowa, będąca w pierwszym wersie (powtarza się głoska drżąca r) brzmieniową ilustracją wspomnianego wyżej wysiłku poznawczego bohatera lirycznego, próbującego dotrzeć do istoty rzeczy, a zarazem ująć ją w języku. Niemoc podmiotu, któremu obiekt poznania „wymyka się” jakiejkolwiek nazwie, została zaakcentowana spółgłoską sonorną: n. Przywołany tutaj brzmieniowy środek stylistyczny nie wystąpił wprawdzie w utworze oryginalnym, ilustruje jednak istotną cechę poetyki Karpowicza, który wzorem Przybosia troszczy się oto, aby jego wiersz był oplątany współbrzmieniami (Dedecius 1982: 132). 
słowo w słowo (Wort für Wort), której ulega niejeden tłumacz. Daje temu wyraz np. w dokonanej przez niego ocenie tłumaczenia tytułu jednego z opowiadań Witolda Gombrowicza: Kluczowa historia Gombrowicza powinna zatem nazywać się inaczej: `Dziecko w mężczyźnie o imieniu Filodor, a nie ২Filodor dzieckiem podszyty. Z polskiego idiomatycznego wyrażenia wyszło idiotyczne niemieckie, z którego wynika, że Gombrowicz jest jakimś schizofrenikiem (Dedecius 1981: 131-132 - tłum. K. K) ${ }^{7}$. W przytoczonej wypowiedzi Dedecius zdaje się sugerować, że dosłowny przekład może doprowadzić do niewłaściwej oceny nawet stanu zdrowia psychicznego autora oryginału. Często jednak „przywiązuje się” do polskich słów pozbawionych odpowiedników niemieckich, które występują w tłumaczonych przez niego lirykach Karpowicza, do tego stopnia, że tworzy neologizmy słowotwórcze, które mogą - jak już kilkakrotnie podkreślałam - budzić sprzeciw adresata przekładu, np. das entlauschte_* Ohr (Dedecius 1965: 48) [wystuchane ucho (Karpowicz 1962: 23)], unterhäutig* (Dedecius 1965: 48) [podskórnie (Kasprowicz 1962: 32)]. Nic dziwnego, że w późniejszych przekładach rezygnuje z nich: pierwsze z wymienionych, niewystępujących w języku niemieckim, słów zastępuje znaną adresatowi przekładu formą imiesłowu drugiego, pochodzącą od czasownika erlauschen (Dedecius 1992: 157; 1996: 21), a drugie wyrażeniem: unter der haut (1996: 20), z pewnością zrozumiałym dla odbiorcy tłumaczonego utworu. Dedecius czyta Karpowicza przez twórczość Leśmiana i poetów awangardowych, co przejawia się np. w naśladowaniu awangardowej metafory, opartej na zestawianiu pojęć odległych znaczeniowo. Posługuje się zazwyczaj - niczym Karpowicz - awangardowym wierszem emocyjnym. Wykorzystuje także metaforę uzasadnioną paronomastycznie (Lektion der Stille, ein mal eins), polegającą nie tylko na powtarzaniu się tych samych głosek w wersie, ale także - jak u Peipera - tych samych cząstek słowotwórczych. Zna poetykę Karpowicza oraz jego awangardowych poprzedników, stosuje środki stylistyczne, które nie wystąpiły wprawdzie w przekładanych przez niego wierszach polskiego autora, ale często pojawiają się w innych utworach poety, np. powtórzenie (Lektion der Stille) czy też instrumentacja głoskowa (Schwieriger wald). Najczęściej stosowanymi przez tłumacza metodami przekładu są immutacja i adiekcja, rzadziej transmutacja i detrakcja. Podobnie postępuje Dedecius w przekładach wier-

${ }^{7}$ Dedecius nie podaje wprawdzie nazwiska autora tłumaczenia, ale znalazłam przekład Waltera Tiela pt. Philodor mit dem Kind unternäht (dosł. Filodor dzieckiem podszyty) (Gombrowicz 1966), o którym najprawdopodobniej pisał autor Polnische Profile. 
szy nieomawianych tutaj poetów lingwistycznych, np. Białoszewskiego, Balcerzana czy też Wirpszy. Czyta ich lirykę przez utwory poetów awangardowych, zwłaszcza Przybosia, stara się oddać w przekładzie cechy wiersza awangardowego, często „stawia” - wbrew swym deklaracjom - na dosłowność, ale to już temat odrębnego szkicu.

\section{Literatura}

Aristoteles, 1992, Nikomachische Ethik, übersetzt v. O. Gigon, München, s. $10-16$.

Barańczak, S., 1971, „II. Szkoła bez uczniów. Tymoteusz Karpowicz albo Polifonia", [w:] Nieufni i zadufani. Romantyzm i klasycyzm w młodej poezji lat sześćdziesiątych, Wrocław, s. 60-61, 67, 75.

Dedecius, K., 1968, Polnische Poesie des 20. Jahrhunderts, München, s. 131, 199, 205-208, 210.

Dedecius, K., 1975, „Versuch der Ganzheit JULIAN PRZYBOŚ und der poetische Sinn", [w:] Polnische Profile, Frankfurt/M., s. 147-195.

Dedecius, K., 1981, „Zwang und Freiheit”, [w:] K. Dedecius, Zur Literatur und Kultur Polens, Frankfurt/M., s. 27-28.

Dedecius, K., 1982, Die Dichter Polens. Hundert Autoren vom Mittelalter bis heute, Frankfurt/M., s. 132-133, 134.

Dedecius, K., 1988, Notatnik tłumacza, przeł. J. Prokop, I. i E. Naganowscy, wstępem opatrzył J. Kwiatkowski, Warszawa, s. 27, 67.

Dedecius, K., 1992, Lyrisches Quintett, Frankfurt/M., s. 157.

Dedecius, K., 1996, „Die Aneignung des Fremdem in der Übersetzung”, [w:] Ost-West Basar, wstęp M. G. von Döhnhoff, Zürich, s. 84-85.

Głowiński, M., 1977, „Świadectwa i style odbioru”, [w:] Style odbioru, Kraków, s. 122.

Gombrowicz, W., 1966, Jungfräulichkeit, übersetzt v. W. Tiel, Vorwort F. Bondy, Reinbeck bei Hamburg.

Herbert, Z., 1964, „Kiesel”, [w:] Gedichte, aus dem Polnischen übertragen und mit Nachwort versehen v. K. Dedecius, Suhrkamp Verlag, Frankfurt/M., s. 76.

Herbert, Z., 1974, „Kiesel”, [w:] Poesiealbum 86, hrsg. v. B. Jentzsch, Auswahl des Heftes B. Jentzsch, übertragen v. K. Dedecius, B. Jentzsch, W. Jöhling, R. Kirsch und H. Oschowsky, Verlag Neues Leben, Berlin, s. 3. 
Herbert, Z., 1979, „Kiesel”, [w:] Inschrift, hrsg. und übertragen v. K. Dedecius, Suhrkamp Verlag, Frankfurt/M., s. 16.

Herbert, Z., 1987, Das Land, nach dem ich mich sehne. Lyrik und Prosa, Auswahl und Vorwort v. M. Krüger, Nachwort J. Błoński, aus dem Polnischen G. von Bierkenfeld, K. Dedecius, K. Staemmler, O. J. Tauschinski i W. Tiel, Suhrkamp Verlag, Frankfurt/M., s. 34.

Herbert, Z., 1996, „Kiesel”, [w:] Panorama der polnischen Literatur des 20. Jahrhunderts, hrsg. und übertragen v. K. Dedecius, Bd. II, Zürich, s. 147.

Herbert, Z., 2000, „Kiesel”, [w:] Herrn Cogitos Vermächtnis. 89 Gedichte, aus dem Polnischen von K. Dedecius, O. J. Tauschinski, K. Staemmler, Suhrkamp Verlag, Frankfurt/M., s. 178.

Karpowicz, T., 1958, „Czarne i białe”, [w:] Kamienna muzyka, Warszawa, s. 53. Karpowicz, T., 1962, „Trudny las”, [w:] W imię znaczenia, Wrocław, s. 23.

Karpowicz, T., 1972, Odwrócone światło, Wrocław-Warszawa-Kraków-Gdańsk.

Karpowicz, T., 1996, Panorama der polnischen Literatur des 20. Jahrhunderts, hrsg. und übertragen v. K. Dedecius, Bd. II, Zürich, s. 20.

Krasoń, K., 2000, „Wizje <<morskie<< T. Karpowicza i J. Przybosia”, [w:] Literackie kresy i bezkresy, red. R. Łozowska, E. Tierling, Szczecin, s. 417$-423$.

Krasoń, K., 2001, „Delikatne napomknienia, czyli motywy biblijne niebędące osnową tematyczną utworów poety (aluzje ukryte)", [w:] Sztuka aluzji literackiej w twórczości lirycznej Tymoteusza Karpowicza, Szczecin, s. $125-127$.

Krasoń, K., 2002, „Echa poezji Przybosia w $<<$ Żywych wymiarach $<<$ Karpowicza", [w:] Stulecie Przybosia, red. S. Balbus i E. Balcerzan, Poznań, s. 79-92.

Krasoń, K., 2003, „Świat poetycki Friedricha Hölderlina w przekładzie artystycznym", Pogranicza, nr 4 (45), s. 118.

Krasoń, K., 2004, „Liryczne wizje Karpowicza a tradycja awangardy (1958-1964)", [w:] Tradycja i nowatorstwo w lirykach i kulturach słowiańskich, red. I. Kowalska-Paszt, J. Czaplińska, A. Horniatko-Szumiłowicz, M. Kuczyńska, Szczecin, s. 33-40.

Leśmian, B., 1988, Gedichte. Polnisch-deutsch, hrsg. und übertragen v. K. Dedecius, Reicheneck.

Leśmian, B., 1996, Panorama der polnischen Literatur des 20. Jahrhunderts, hrsg. und übertragen v. K. Dedecius, Bd. I, Zürich, s. 117-136.

Lipski, J. J., 1962, „Ku intelektualistycznemu symbolizmowi”, Twórczość, nr 5, s. 94. 
Mróz, K., 1977, „Przekład jako problem estetyczny”, [w:] Między oryginałem a przekładem, red. M. Filipowicz-Rudek, J. Konieczna-Twardzikowa, M. Stoch, Warszawa, s. 41.

Naganowski, E., 1972, „Kochanek polskich muz”, [w:] K. Dedecius, Polacy i Niemcy. Posłannictwo książek, tłum. E. Naganowski, Kraków, s. 5-19.

Neue polnische Lyrik, Ausgewählt und übertragen v. K. Dedecius, Darmstadt 1965.

Przyboś, J., 1989, Poesie und Poetik, hrsg. und aus dem Polnischen übertragen v. K. Dedecius, Frankfurt/M.

Saussure, F. de, 1961, Kurs językoznawstwa ogólnego, tłum. K. Kasprzyk, Warszawa, s. 43.

Szmydt, A., 1958, „W poszukiwaniu poetyki”, Nowa Kultura, nr 30.

Schlegel, A. W., 1928, Über die Bhagavad - Gita, t. 2, z. 2, Bonn, s. 36-42.

Schultze, B., Matuschek H., 2005, „Sprachliche Asymmmetrien als Beobachtungsort polnisch-deutscher literarischer Übersetzungen", Zeitschrift für Slavistik, z. 1-2 (w druku).

Trznadel, J., 1972, „Metafizyczna Silva Rerum”, Twórczość, nr 10, s. 76.

Ziomek, J., 1980, „Parodia jako problem retoryki”, [w:] Powinowactwa literatury, Warszawa, s. 355-387.

\section{Wykorzystane w pracy znaki}

//\# - znak oddzielający poszczególne strofy.

_ * - znak wskazujący na „sztuczną" konstrukcję składniową, niedającą się zaakceptować przez niemieckiego czytelnika, będącą zazwyczaj kalką polskiego wyrażenia lub zwrotu.

*[...]!!!- znak oznaczający opuszczenie w przekładzie fragmentu orygina- 
łu, który jest ważny dla interpretacji literackiego pierwowzoru.

\section{On translations of lyrics of Tymoteusz Karpowicz by Karl Dedecius (summary)}

In the paper an attempt was made to perform both thorough analysis and evaluation of Carl Dedecius' translations of two poems of Tymoteusz Karpowicz: Black and white and Hard forest. The starting point of this analysis are thoughts and ideas of the interpreter concerning translation of lyrics. This gives, in a way, an answer to the problem of how rigorously Dedecius applied his theory. In the conclusion it is pointed out that for the interpreter sounding was a priority, although wordphrases and sentences were also taken into account. However, some of the general sense was lost. The author remarks that Carl Dedecius interprets Karpowicz through poetry of Leśmian and avantgarde poets.

The author remarked that the interpreter seems not to notice problems of metalinguistics, present in Karpowicz's lyrics. 